\title{
Effects of Materials Properties on Strength and Deflection of Optimized R.C. Beams: Genetic Algorithms
}

\author{
Salim T. Yousif \\ Assistant Prof. \\ Civil Eng. Dept. - Mosul University
}

Rabi' M. Najem

Assistant Lecturer

Civil Eng. Dept. - Mosul University

\begin{abstract}
The Genetic Algorithms GAs, which is a powerful procedure of finding the optimum solution for constraints optimization, was used to find the optimum cost of reinforced concrete beams subjected to flexural constraints, with the limitations for section dimensions and steel reinforcement ratio according to the ACI Code 2011.

After designing the sections optimally, a non linear analysis was carried out to check the capacity of the designed section, and to find out the effect of the materials properties on the beam's deflection. Eight node degenerated shell elements are used to represents the beam in the analysis procedure; ten layers were used to represent the concrete through the optimum section and one layer to represent the steel reinforcement.

It was found from the results that the materials properties affect the optimal designed sections in a way that the response of these sections towards strength and deflection, should be taken into consideration through designing the beams, if optimal design is required which was affected by about $5-19 \%$.

$$
\begin{aligned}
& \text { الأمثل: طريقة الخوارزميات الجينية }
\end{aligned}
$$

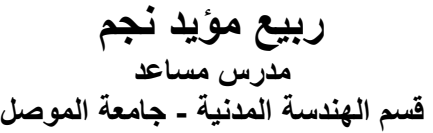

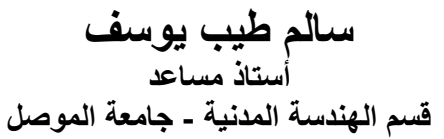$$
\text { تأثير خصائص المواد على مقاومة وانحراف العتبات الخرساتية المسلحة ذات التصميم }
$$

الخلاصة

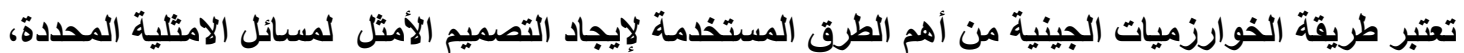

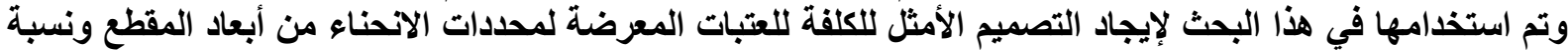

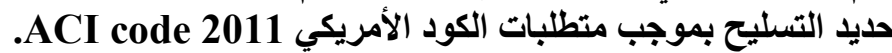

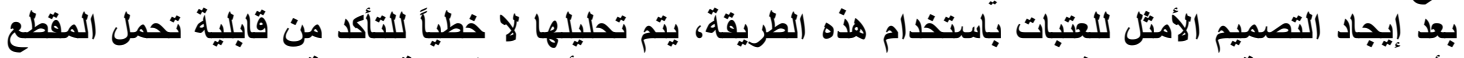

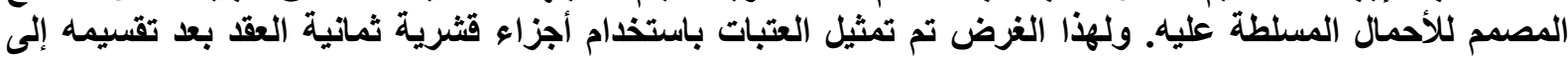

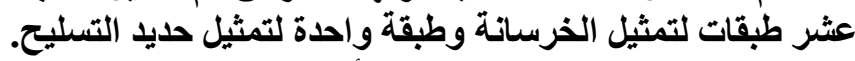

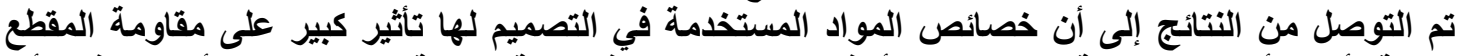

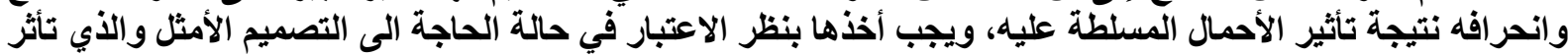
بنسبة تتراوح مابين 5 - 19 \% تصأبرل
\end{abstract}

Key Words

Optimization, Genetic Algorithm, Optimum Cost Design. Reinforced Concrete.

Received: 8 - 10 - 2012

Accepted: $22-10-2013$ 


\section{List of Symbols}

$\begin{array}{cl}\mathrm{b} & : \text { Width of the section }(\mathrm{mm}) \\ \mathrm{C}_{\mathrm{c}} & : \text { Cost of concrete } / \mathrm{m}^{3} \\ \mathrm{C}_{\mathrm{s}} & : \text { Cost of steel } / \mathrm{m}^{3} \\ \mathrm{C}_{\mathrm{t}} & : \text { Total cost of the section } / \mathrm{m}^{3} \\ \mathrm{~d} & : \text { Effective depth of the section }(\mathrm{mm}) \\ f_{\mathrm{c}}^{-} & : \text {Concrete compressive strength }(\mathrm{MPa}) \\ f_{\mathrm{y}} & : \text { Steel yield stress }(\mathrm{MPa}) \\ \mathrm{h} & : \text { Total depth of section }(\mathrm{mm}) \\ \mathrm{h}_{\min } & : \text { Minimum depth of section }(\mathrm{mm}) \\ \mathrm{k} & : \text { Moment design factor } \\ \mathrm{L} & : \text { Length of beam }(\mathrm{mm}) \\ \mathrm{r} & : \text { A ratio between the cost of steel and cost of concrete }\left(\mathrm{C}_{\mathrm{s}} / \mathrm{C}_{\mathrm{c}}\right) \\ \mathrm{t} & : \text { Clear cover of the section }(\mathrm{mm}) \\ \mathrm{Vol}_{\mathrm{c}} & : \text { Volume of concrete }\left(\mathrm{m}^{3}\right) \\ \mathrm{Vol}_{\mathrm{s}} & : \text { Volume of steel }\left(\mathrm{m}^{3}\right) \\ \mathrm{W} & : \text { Applied load }(\mathrm{kN}) \\ \rho & : \text { Steel reinforcement ratio } \\ \rho_{\min } & : \text { Minimum reinforcement ratio } \\ \rho_{\max } & : \text { Maximum reinforcement ratio }\end{array}$

\section{Introduction}

Optimization is the process of obtaining maximum or minimum value of an objective function while subjected to various constraints. Thus, the motive of optimal design is to obtain the best possible design following a set of pre-selected measures of effectiveness. The awareness of the scarcity of natural resources drives towards light weight and low cost when it comes to structures, thus emphasizing the need for weight and cost optimization beside shape and topology optimization of structures. Many mathematical methods can be used to solve this kind of problems; one of these methods is the Genetic Algorithms that was used in this study.

The GAs holds a population of individuals (chromosomes), which evolve selection and other operators like crossover and mutation. Every individual in the population gets an evaluation of its adaptation (fitness) to the environment. In terms of optimization this means that the function maximizes or minimizes is evaluated for every individual. The selection chooses the best gene combinations (individuals), which through crossover and mutation should drive to better solutions in the next population [1]. The most often used schemes of GAs are:

1. The initial population is randomly generated, by selecting the genes of the chromosomes among the allowed alphabet for the gene. Because of the easier computational procedure it is accepted that all populations have the same number $(\mathrm{N})$ of individuals.

2. Calculation the values of the fitness function that wanted to be minimized or maximized for each individual. 
3. Selection, between all individuals in the current population are chosen those, which will continue and by means of crossover and mutation will produce offspring population. At this stage elitism could be used; that best individuals are directly transferred to the next generation. The elitism guarantees, the value of optimization function cannot be worst.

4. Crossover, the individuals chosen by selection recombine with each other and new individuals will be created. The aim is to get offspring individuals, that inherit the best possible combination of the characteristics (genes) of their parents.

5. Mutation, by means of random change of some of the genes, it is guaranteed that even if none of the individuals contain the necessary gene value for the optimum solution, it is still possible to reach it.

6. New generation, the elite individuals chosen from the selection are combined with those who passed the crossover and mutation, and form the next generation.

7. Check for termination of the algorithm, as in the most optimization algorithms, it is possible to stop the genetic optimization.

This paper deals with some of the factors that affect strength and deflection of reinforced concrete beam sections which were originally designed optimally according to their materials cost.

The genetic algorithm was used to find the optimal solution of reinforced concrete frames [2]. Each frame was represented by a three string chromosome, one for the beam's group and the other strings for the columns group. Each internal moment was normalized with respect to the corresponding member strength in order to transform the constrained optimization problem to an unconstrained one and the genetic algorithm can be applied then. It was found that the pre-selection operator in addition to the three basic operators of the GAs, successfully led the randomly distributed initial design points in the design space to the local optimum design points, and this algorithm can be applied to the discrete optimization of three - dimensional reinforced concrete frames.

Reinforced concrete plane frames were designed using the sequential quadratic programming with MATLAB [3], taking into consideration material and labor cost for forming and placing concrete. The study constraints on the span length of a multi bay - single story structure. In addition, on the story numbers of a single bay - multi story structure and their effects on the total cost, It was found that the design of any structure of this kind will become uneconomic at a certain limits according to design code specifications concerning section dimensions and reinforcing steel.

Two new penalty functions were introduced [4], with their proof of convergence which have better convergence properties to the structural optimization problems, by improving the penalty parameter through the optimization procedure instead of keeping it as a fixed value through the solution and this did improve the convergence rate and the final results.

The external penalty function method was used in finding the optimum cost design of reinforced concrete underground penstock [5], taking the reinforcement ratio of the inner ring rebar, outer ring rebar and the tube wall thickness as the design variables. The design solution was constraints by geography constraints to limit the wall dimensions and the reinforcement 
ratio, strength constraints to limit the tensile strength of concrete and finally deformation constraints to control the radial deformation. Due to the optimized design results, the rate of reinforcement rebar decreased by $15 \%$.

A Visual Basic program was developed to find the optimum cost design of reinforced concrete flat slab [6], by using the Reactive Taboo method, which in general, uses previous information to prevent entrapment at local minimum at some points by applying taboo conditions. The slab thickness is the only design variable used in this study, taking into considerations limiting some constraints, like span - depth ratio to prevent excessive deflection. In addition, the shear stress was used as a design constraint with the punching shear, the results showed that for a certain slab length of $6200 \mathrm{~mm}$ with a specified load conditions, the optimum thickness was $153 \mathrm{~mm}$, which was the same answer that was given by the traditional GAs for the same loading conditions. The GAs was used to find the optimum cost of pre-cast concrete floors [7]. The objective function was formed to take into account the cost of materials consumption, labor, manufacture, indirect costs, storage, transport, assembly, taxes and profits, as shown in Fig.(1).

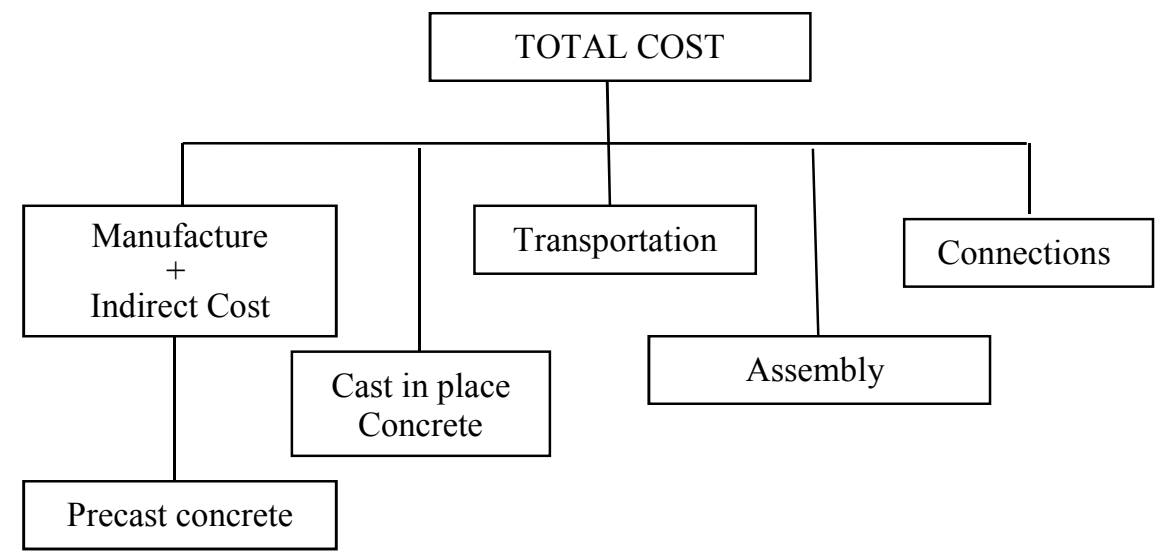

Fig. (1) Activities accounted for the cost function[7]

Limit the number of floors, floors height, beam width, dead and live loads, and floor dimensions. Take the following design variables: cross sectional dimensions of the beam, slab thickness, direction of the hollow slab, reinforcement steel and number of strands. Two new genetic operators were proposed in this study [7]. The first one (Transgenic), automatically modified the number of strands to keep the number of the first layer larger than the second layer. Since it resists a smaller bending moment, and the second one (Twins), was implemented to check if the individuals from elitism were the same and in case they were, one of the twins was placed to crossover and the next one in the rank was taken to the elitism.

\section{Objective Function}

For this case, the design criterion is the cost of the reinforced concrete beam. The objective is to minimize the cost without violating the constraints. The cost of the beam includes the cost of the concrete and the cost of the reinforcing steel. The total cost of the reinforced concrete beam is:

$\mathrm{C}_{\mathrm{t}}=\mathrm{Vol}_{\mathrm{c}} \mathrm{C}_{\mathrm{c}}+\mathrm{Vol}_{\mathrm{s}} \mathrm{C}_{\mathrm{s}}$ 
After representing the volume of concrete with its design variables (width and effective depth) and representing the reinforcing steel with its design variables (reinforcement ratio with the beam width and effective depth), the cost function can be expressed as follow:

$\mathrm{C}_{\mathrm{t}}=\mathrm{C}_{\mathrm{c}} \times \mathrm{b} \times\{(\mathrm{d}+\mathrm{t})+\mathrm{r} \times \rho \times \mathrm{d}\}$

where: $r$ represent the ratio of $1 \mathrm{~m}^{3}$ steel cost to a $1 \mathrm{~m}^{3}$ concrete cost, which was equal to 75 in this study. Since the weight of $1 \mathrm{~m}^{3}$ of steel is equal to $7850 \mathrm{~kg}$, with price of $750000 \mathrm{ID}$, and the price of $1 \mathrm{~m}^{3}$ of concrete is equal to $75000 \mathrm{ID}$, so the cost ratio of $1 \mathrm{~m}^{3}$ of reinforced concrete will be $(r=7850 \times 750000 / 75000)$ which is about 78.5 .

\section{Design Variables}

The design variables shown in Fig. (2), have width (b), and effective depth (d) of the indicated section. Reinforcing area of steel with the number of bars and topology of the flexural reinforcement $\left(\mathrm{A}_{\mathrm{s}}\right)$.

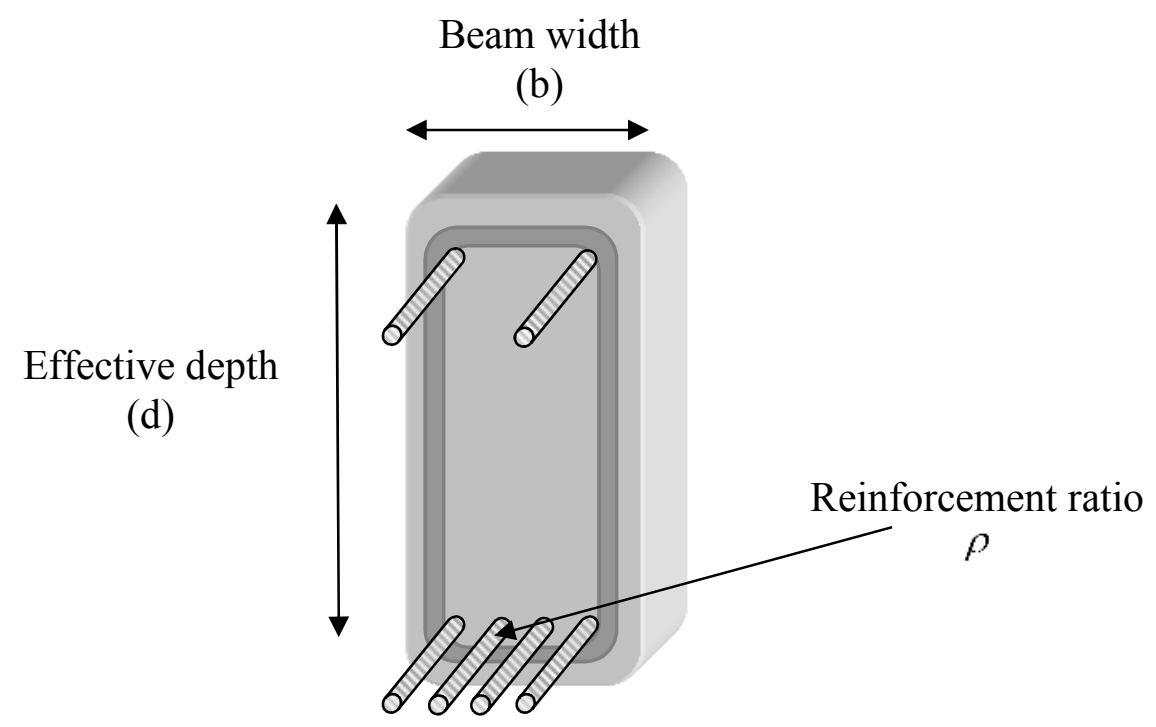

Fig. (2) Reinforced concrete beam design variables

\section{Design Constraints}

A reinforced concrete beam must have a structural capacity greater than the factored applied loading and meet specifications defined in the ACI Code. The ACI Code has restrictions and limitations on the cross-sectional geometry of beam and position and quantity of steel reinforcement for all kinds of loading.

Many researchers used the dimensions only as design variables, and then the reinforcement ratio was calculated depending on these variables [8], then it was topology optimized, on the contrary, of this study, which used the reinforcement ratio as a design variable in addition to the dimensions (which will give the minimum cost). The constraints were used in order to specify the main variables in such a case where they can resist the applied loads (in many ways), and also to stay within the limits of the used code, in order to make the optimal solution more realistic and applicable.

The first constraint Eq.(3) was used to make the three variables, $\rho b$ and $d$ (reinforcement ratio, beam width and beam effective depth) of the section carry the smallest values that can resist the applied moment on that section. While Eqs. (4) \& (5) represent the 
constraints used to prevent the reinforcement ratio neither from exceeding the maximum value nor below the minimum value specified according to the ACI Code.

$$
\begin{aligned}
& \frac{\mathrm{k} \times \mathrm{w} \times \mathrm{L}^{2}}{0.9\left(\rho \times \mathrm{b} \times \mathrm{d} \times \mathrm{f}_{\mathrm{y}} \times\left(\mathrm{d}-\frac{\left(\rho \times \mathrm{b} \times \mathrm{d} \times \mathrm{f}_{\mathrm{y}} / 0.85 \times \mathrm{f}_{\mathrm{c}}^{-} \times \mathrm{b}\right)}{2}\right)\right)}-1 \leq 00 \\
& 1-\frac{\rho_{g}}{\rho_{\min }} \leq 001 \\
& \frac{\rho}{\rho_{\max }}-1 \leq 001 \\
& \rho_{\min }=\frac{0.25 \times \sqrt{f_{c}^{-}}}{f_{y}} \geq \frac{1.4}{f_{y}} \\
& \rho_{\max }=0.85 \times \beta 1 \times \frac{f_{c}^{-}}{f_{y}} \times \frac{0.003}{0.003+0.005} \\
& \rho_{g}=\frac{A_{s}}{b \times h}
\end{aligned}
$$

Eq. (9) is used to guarantee that the optimum section will not have depth less than the depth that control the elastic deflection, ACI code (9.5.2.2), considering effects of cracking and reinforcement on member stiffness [9].

$1-\frac{h}{h_{\min }} \leq 0$

In order to make the dimensions more realistic, Eqs. (10) \& (11) are used to keep the ratio of the optimum depth to the optimum width between (1.5) \& (2.5), (specified by the designer).

$1.5-\frac{h}{b} \leq 0$

$$
\frac{h}{b}-2.5 \leq 0
$$

While keeping the dimensions of the optimum width in the range $(200 \mathrm{~mm}) \&(500$ $\mathrm{mm})$, and the optimum depth in the range $(300 \mathrm{~mm}) \&(1250 \mathrm{~mm})$, which have been used through the Eqs. (12) \& (13), also (specified by the designer). 
$\left(1-\frac{b}{200 m m} \leq 0\right)$ and $\left(\frac{b}{500 m m}-1 \leq 0\right)$

$\left(\frac{h}{1250 \mathrm{~mm}}-1 \leq 0\right)$ and $\left(1-\frac{h}{300 \mathrm{~mm}} \leq 0\right)$

\section{Non Linear Analysis and Finite Elements Representation}

To check the capacity of the designed section, a non linear analysis was carried out for the optimum designed beam section. After designing the section optimally using the GAs, the optimum design results that represent the actual optimum section will be used to analyze the section non linearly.

The eight-node serendipity degenerated shell element shown in Fig. (3), was used in the finite element representation with a normal integration rule using (3x3) Gauss points. Five degrees of freedom are specified at each nodal point, corresponding to its three displacements and two rotations of the normal at the node.

Through the thickness direction, where a linear variation of strain is assumed, two Gauss points are sufficient to capture the bending behavior in linear material problem, while higher order Gaussian quadrature rules (for instance 5 - 7 Gauss points) have been advocated for nonlinear material problems as for this case, CONCR1 Software was used for this purpose [10].

Incremental and iterative Modified Newton - Raphson scheme are employed in the solution, with a recalculation from the second iteration for each load increment concerning the tangential stiffness matrix.

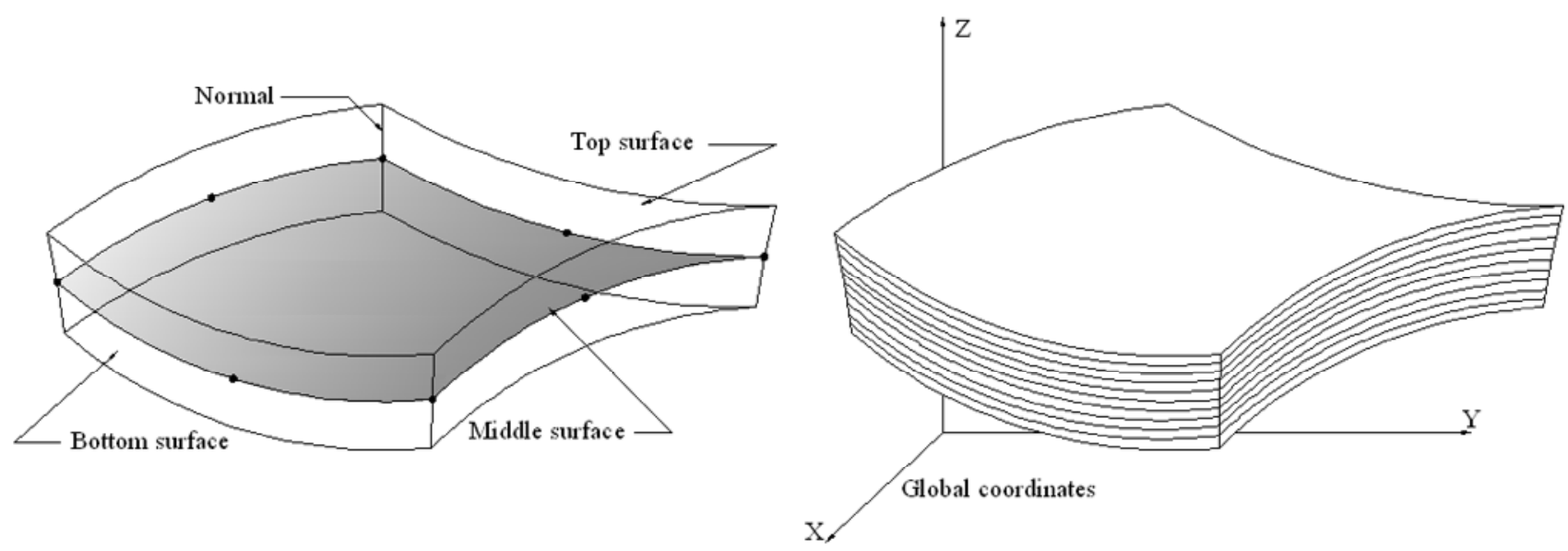

Fig. (3) Eight - node degenerated shell element

\subsection{Layered model}

A simple and general procedure to discretize and integrate through the beam's thickness is offered by the so-called layered model. The section is built up from a series of layers of different materials. In this linear material problem, the stress profile in the thickness direction should be known, so a midpoint rule integration scheme is adopted for each layer.

Layers are numbered sequentially, starting at the bottom surface of the section. Each layer contains three points on its mid surface. The stress components of the layer are computed at these points and assumed to be constant over the thickness of each layer. 
Accordingly, the actual stress distribution of the section is modeled by a piecewise constant approximation, as shown in Fig. (4). Layers of different thicknesses can be employed as well as different number of layers per element.

The stress resultant can be obtained by integrating the corresponding stress components with respect to the thickness coordinate of the section.

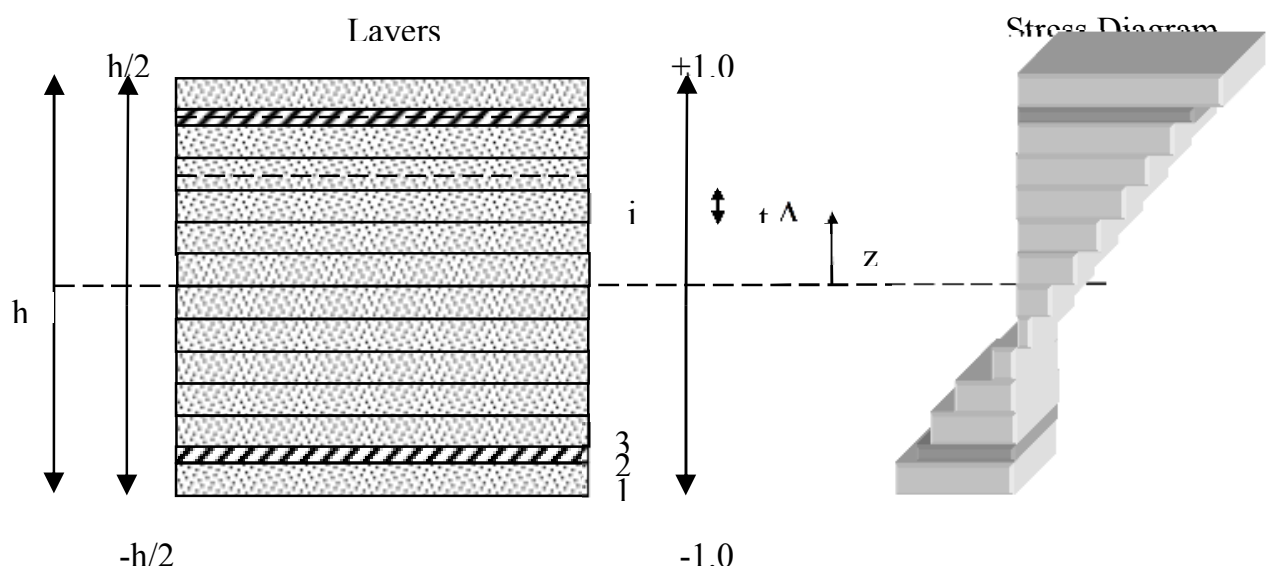

Fig. (4) Layered model and the corresponding stress representation

\section{Numerical Examples}

\subsection{Cantilever beam}

A $3500 \mathrm{~mm}$ cantilever beam with a rectangular cross section was designed optimally using the GAs, the beam was under a concentrated load of $150 \mathrm{kN}$, the optimum designed section is shown in Fig. (5) with the optimum results. The material properties of the beam were: $f_{c}^{-}=30 \mathrm{MPa}$ and $\mathrm{f}_{\mathrm{y}}=400 \mathrm{MPa}$, the steel to concrete cost ratio was 75 .

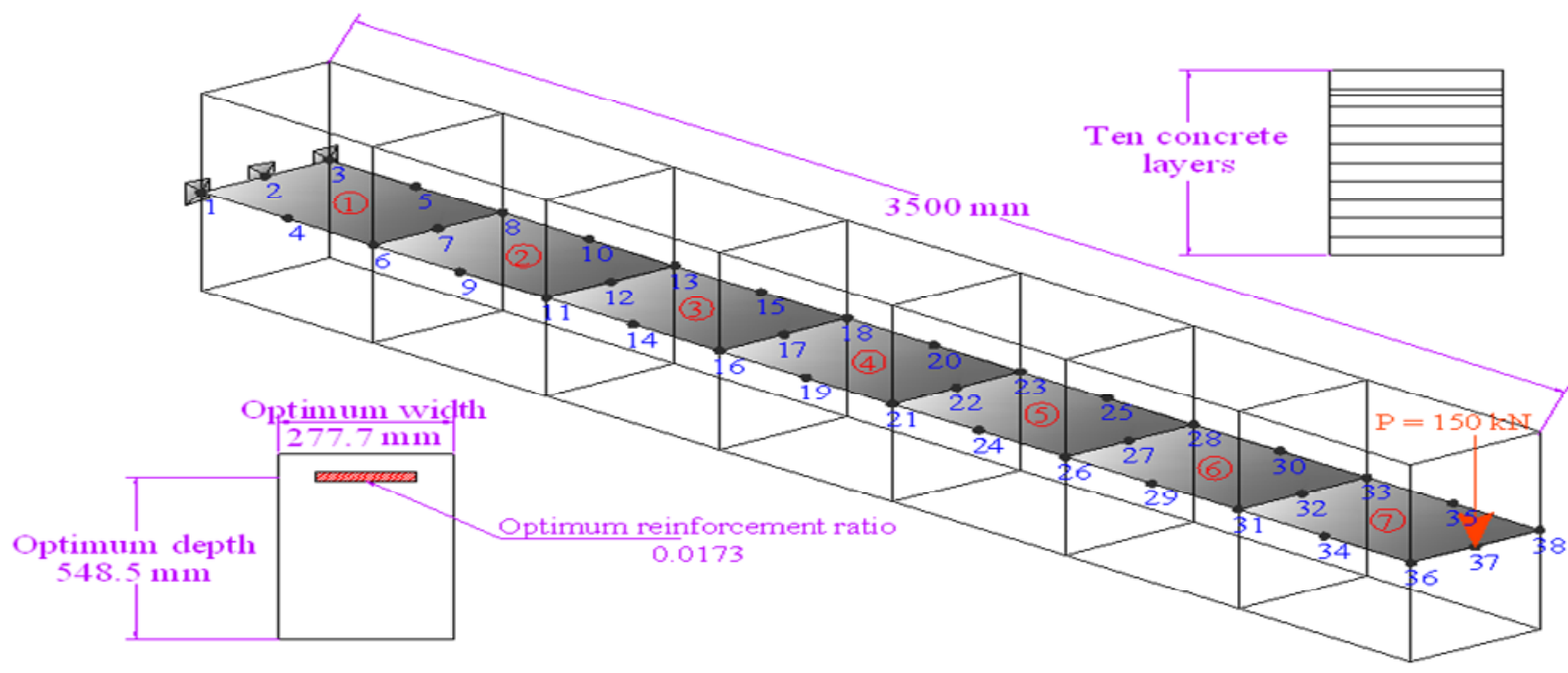

Fig. (5) Finite elements representation of a cantilever beam example 
The beam is analyzed non linearly using seven elements in the longitudinal direction with one element for the width, and 38 nodes for the whole beam. The load was applied at node 37 .

The cross section was divided into ten concrete layers. One equivalent layer represents the steel in the negative moment area as shown in Fig. (5).

Fig. (6), represents the load - deflection curve of the beam, showing the cracking load of about $(23.75 \mathrm{kN})$ and the failure load of $(164.35 \mathrm{kN})$

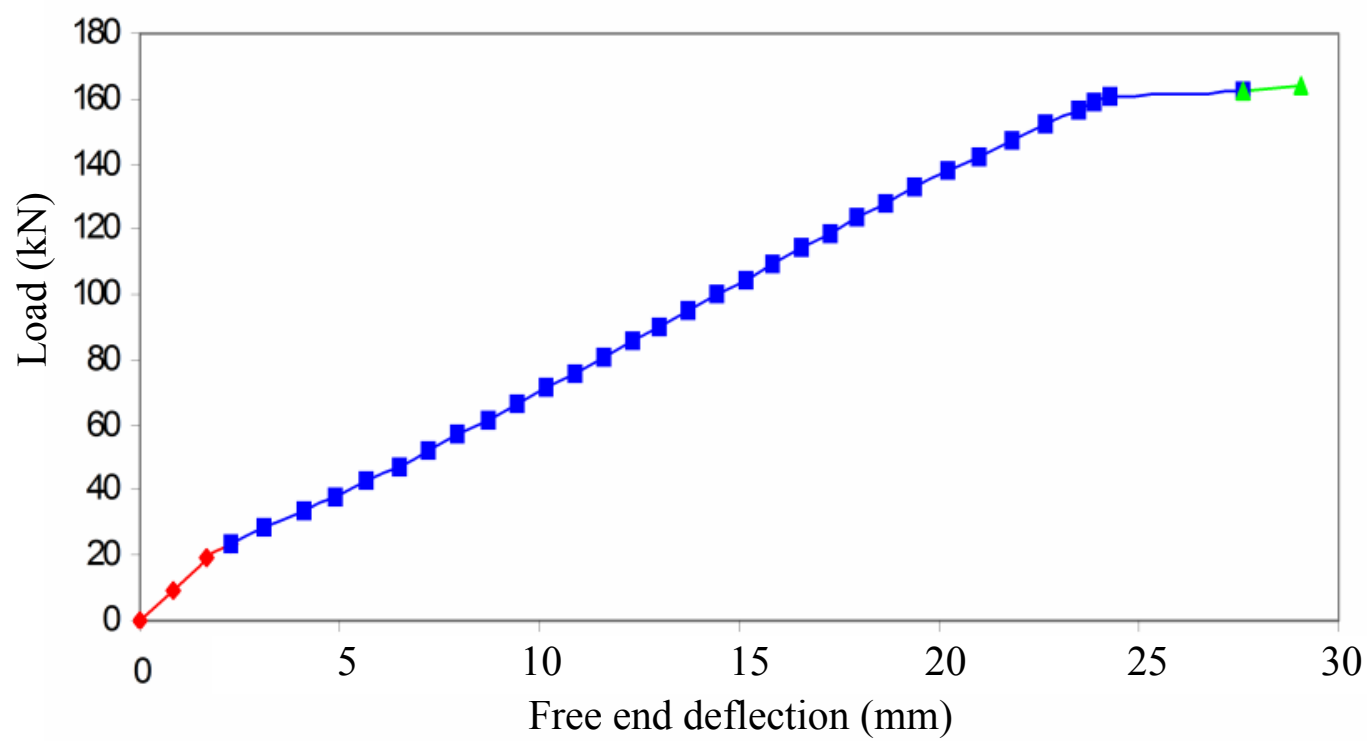

Fig. (6) Free end section displacement of cantilever beam example

For the same example, few other beam sections were designed optimally by changing the span length and analyzing to get the ultimate load. The results are shown in Table (1). The beams were divided into number of elements, according to the span length, with a length of each element equals to $500 \mathrm{~mm}$ and width equal to the designed beam width. The material properties were $\mathrm{f}_{\mathrm{y}}=400 \mathrm{MPa}$ and $\mathrm{f}_{\mathrm{c}}^{-}=30 \mathrm{MPa}$, cost ratio $\mathrm{r}=75$ and the load was $150 \mathrm{kN}$ applied at the free end of the beam. The beams cross sections were divided into ten concrete layers with one equivalent layer to represent the steel reinforcement area. As it can be seen from the table, all the section capacities of the optimum designed beams are marginally greater than the applied load, with a difference of about 7 to $14 \%$.

Table (1) Optimum design and analysis results of different length cantilever beams

\begin{tabular}{|c|c|c|c|c|c|c|}
\hline & \multicolumn{2}{|c|}{ GAs optimum design results } & \multicolumn{2}{c|}{ Analysis results } & Difference \\
\hline $\begin{array}{c}\text { Beam } \\
\text { length } \\
(\mathbf{m m})\end{array}$ & $\begin{array}{c}\text { Width of } \\
\text { the section } \\
(\mathbf{m m})\end{array}$ & $\begin{array}{c}\text { Height of } \\
\text { the section } \\
(\mathbf{m m})\end{array}$ & $\begin{array}{c}\text { Reinforceme } \\
\mathbf{n t} \text { area } \\
\left.\mathbf{m m m}^{\mathbf{2}}\right)\end{array}$ & $\begin{array}{c}\text { Cracking } \\
\text { load (kN) }\end{array}$ & $\begin{array}{c}\text { Failure } \\
\text { load (kN) }\end{array}$ & $\begin{array}{c}\text { percent from the } \\
\text { applied load }\end{array}$ \\
\hline 2500 & 245 & 539 & 2020 & 23.75 & 160.55 & $7 \%$ \\
\hline 3000 & 262.5 & 577.4 & 2338 & 23.75 & 162.45 & $8.3 \%$ \\
\hline 3500 & 277.7 & 611 & 2635 & 23.75 & 164.35 & $9.6 \%$ \\
\hline 4000 & 291.4 & 641 & 2916 & 23.75 & 166.25 & $10.8 \%$ \\
\hline 4500 & 303.8 & 668.3 & 3184 & 28.5 & 171.475 & $14.3 \%$ \\
\hline
\end{tabular}




\subsection{Simply supported beam}

Another beam was designed optimally using the GAs as shown in Fig. (7), the designed beam was simply supported with $4.5 \mathrm{~m}$ span length and rectangular cross section loaded by two concentrated loads of $200 \mathrm{kN}$ each, applied at the middle third of the span length, the material properties were: $\mathrm{f}_{\mathrm{c}}^{-}=25 \mathrm{MPa}$ and $\mathrm{f}_{\mathrm{y}}=400 \mathrm{MPa}$, and the cost ratio was equal to 75

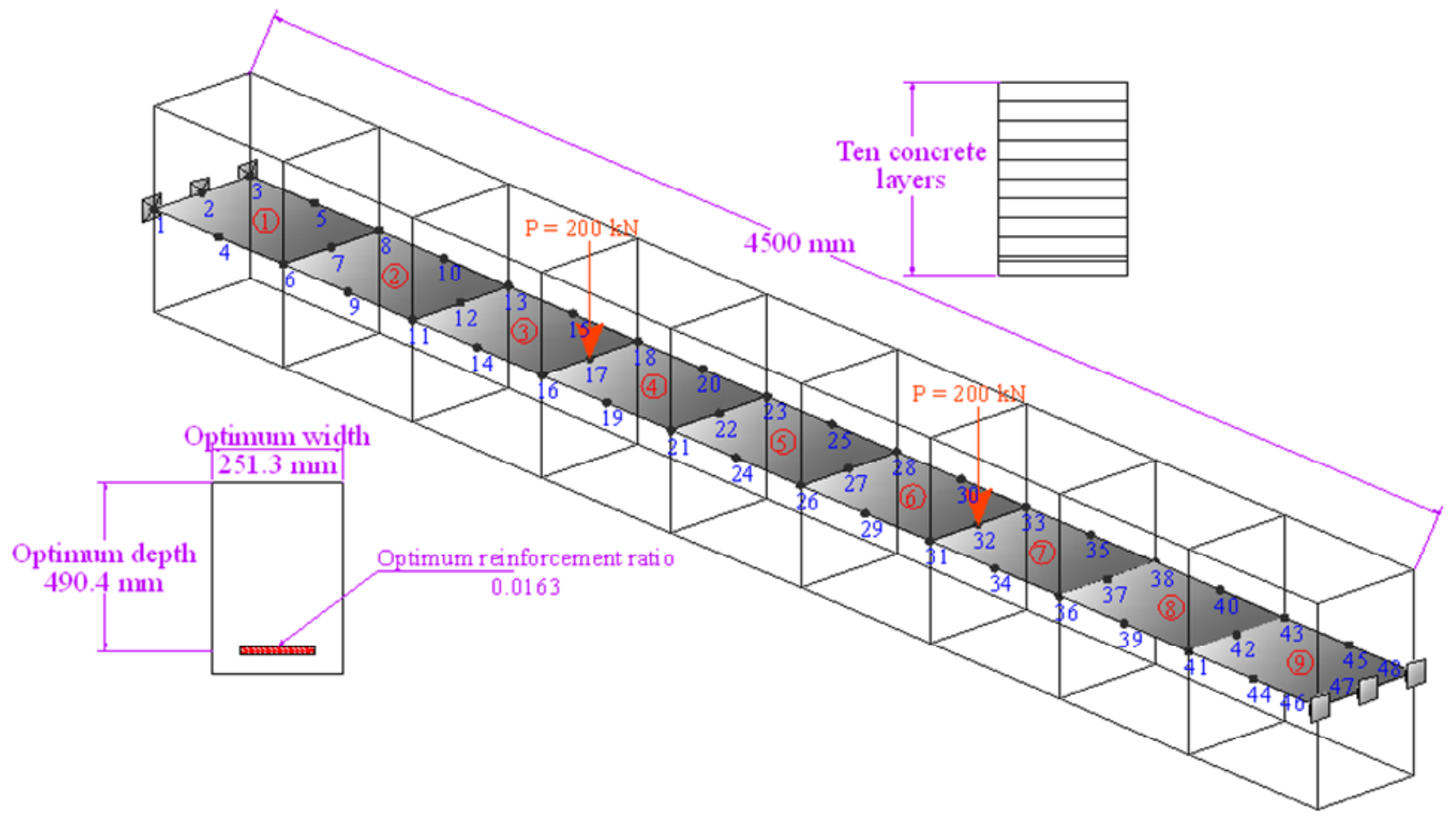

Fig. (7) Finite elements representation of a simply supported beam example

The designed beam was analyzed non linearly using nine elements in the span direction. The cross section was divided into ten layers to represents the concrete. One layer was used to model the steel reinforcement, as shown in Fig. (7). Fig. (8) shows that the cracking load is $(75 \mathrm{kN})$ and the failure load is $(443.75 \mathrm{kN})$.

Other simply supported beam examples were designed optimally using the GAs, analyzed non linearly to check the capacity of the designed sections. The span of the previous example was changed many times, using the same number of elements for analyzing each beam, the length of the element in each beam is different from the other, the width and height of the used element are equal to the optimum designed width and height of the beam. The design and analysis results are shown in Table (2). It is seen that the sections capacities are larger than the applied design load by about $10 \%$, which is acceptable for design purposes. 


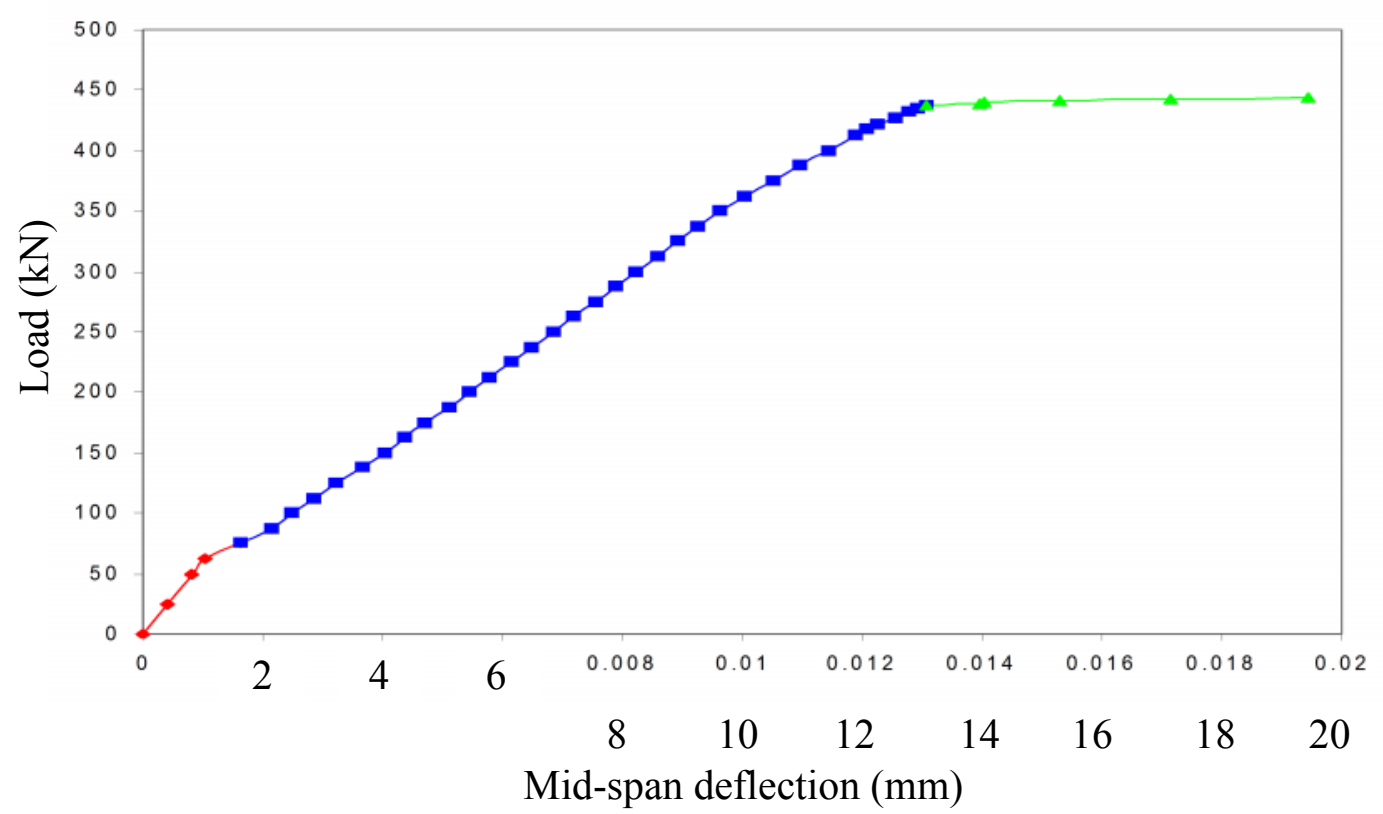

Fig. (8) Mid-span displacement of simply supported beam example

Table (2) Optimum design and analysis results of different length simply supported beams

\begin{tabular}{|c|c|c|c|c|c|c|}
\hline & \multicolumn{3}{|c|}{ GAs optimum design results } & \multicolumn{2}{|c|}{ Analysis results } & \multirow[b]{2}{*}{$\begin{array}{c}\text { Difference } \\
\text { percent from } \\
\text { the applied load }\end{array}$} \\
\hline $\begin{array}{l}\text { Beam } \\
\text { length } \\
(\mathrm{mm}) \\
\end{array}$ & $\begin{array}{l}\text { Width of } \\
\text { section } \\
(\mathrm{mm}) \\
\end{array}$ & $\begin{array}{l}\text { Height of } \\
\text { section } \\
(\mathrm{mm}) \\
\end{array}$ & $\begin{array}{c}\text { Reinforce } \\
\text { ment area } \\
\left(\mathrm{mm}^{2}\right)\end{array}$ & \begin{tabular}{|l|} 
Cracking \\
$\operatorname{load}(k N)$
\end{tabular} & $\begin{array}{c}\text { Failure } \\
\text { load } \\
(\mathbf{k N})\end{array}$ & \\
\hline 3300 & 288.5 & 502.7 & 1640 & 75 & 436.25 & $9 \%$ \\
\hline 3600 & 234.7 & 516.3 & 1736 & 75 & 437.5 & $9.4 \%$ \\
\hline 3900 & 240.5 & 529.1 & 1829 & 75 & 441.25 & $10.3 \%$ \\
\hline 4200 & 246 & 541.3 & 1920 & 75 & 442.5 & $10.6 \%$ \\
\hline 4500 & 251.3 & 552.9 & 2009 & 75 & 443.75 & $10.9 \%$ \\
\hline
\end{tabular}

Since the designed sections capacities are sufficient to resist the applied load with a difference within $10 \%$, there is no need to check the sections with reanalysis. The GAs proved that it is capable of finding the exact or near exact optimum solution with minimum constraints violation.

\subsection{Effect of $f_{c}^{-}$And $f_{y}$ on the Deflection}

A $3500 \mathrm{~mm}$ cantilever beam loaded with $200 \mathrm{kN}$ concentrated load at the free end as shown in Fig. (9), was designed optimally using the GAs with different values of $f_{c}^{-}$and $f_{y}$.

Figs. (10-14), represents the load-deflection curves for the designed beams. The three curves in each figure stands for a three different values of $f_{y}(276,345$ and $400 \mathrm{MPa})$ and the same value of $f_{c}{ }^{-}$. Obviously, increasing the grade of $f_{y}$ decreases the cost of the designed section, this is because of choosing less reinforcement ratio when using higher grade of $f_{y}$ by the GAs optimum solver. Also, increasing $f_{y}$ grade will decrease the cross sectional area , 
causing more savings in the optimum cost. The cost savings already caused by increasing the compressive strength of concrete are shown in Fig. (15).

It can be seen from Table (3), that increasing $f_{c}^{-}$and $f_{y}$ will decreases the optimum design variable and the optimum cost except the converse effect of concrete compressive strength on the optimum reinforcement ratio, which is postulated. Also, not only the reinforcement ratio increases by the compressive strength of the concrete, the ultimate load of the optimally designed section seems to witness an augmentation of its own by increasing $f_{c}{ }^{-}$. On the contrast, $\mathrm{f}_{\mathrm{y}}$ has a different effect on the ultimate load, as shown in Fig. (16) and (17). The cost savings through changing the concrete compressive strength for the same value of $f_{y}$ is shown in Table (3), and a little more when the yield stress is higher, as it can be seen in Fig. (18).

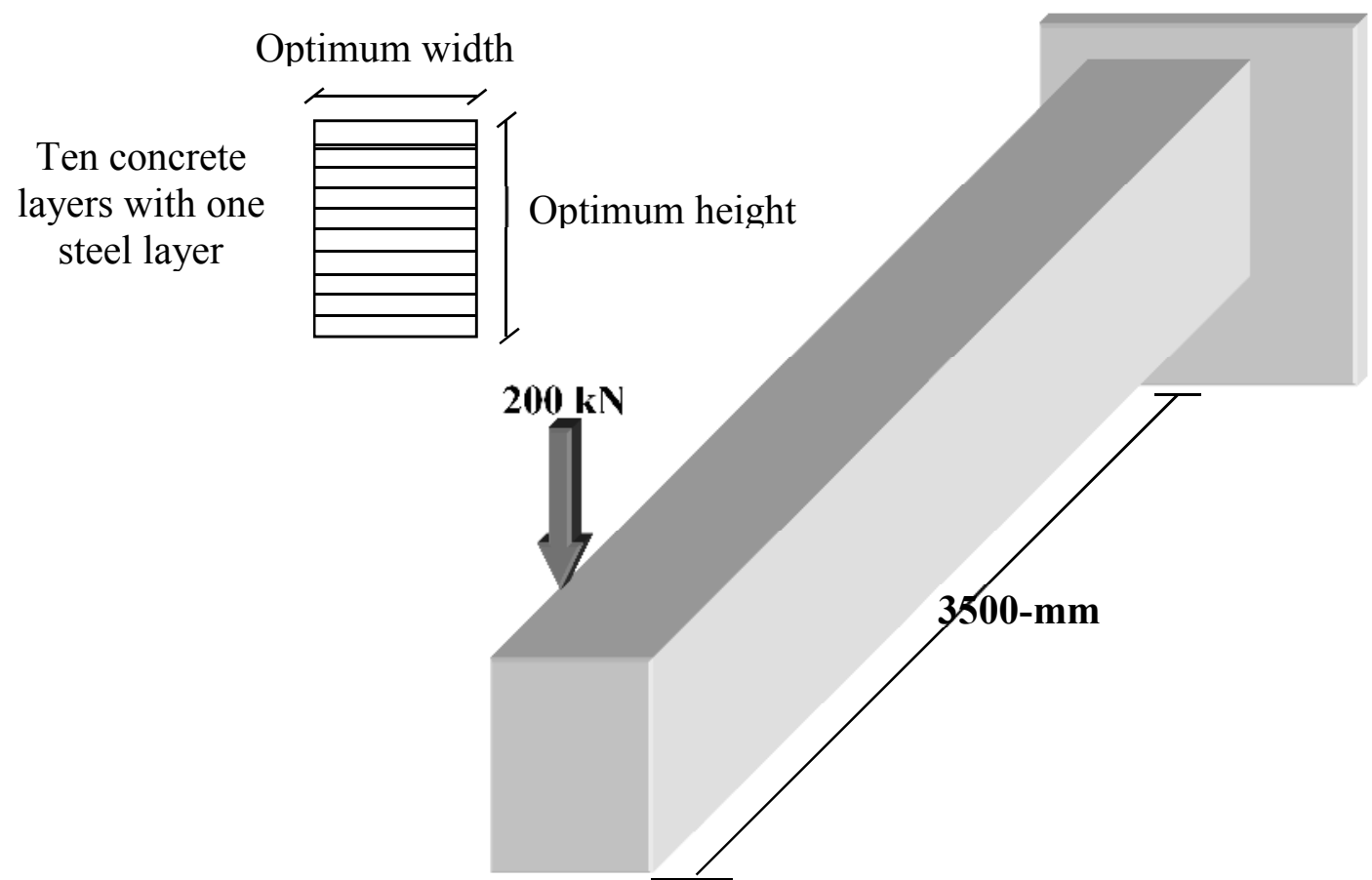

Fig. (9) Cantilever beam loaded with $200 \mathrm{kN}$, optimally designed

Table (3) Optimum design results for cantilever beams with different values of $f_{c}^{-}$and $f_{y}$

\begin{tabular}{|c|c|c|c|c|c|c|c|}
\hline & & \multicolumn{5}{|c|}{ Concrete compressive strength (MPa) } & \\
\hline & $\begin{array}{c}\text { Optimum design } \\
\text { variables }\end{array}$ & $\begin{array}{c}\mathbf{f}_{\mathrm{c}}^{-}=\mathbf{2 0} \\
\mathrm{MPa}\end{array}$ & $\begin{array}{l}\mathrm{f}_{\mathrm{c}}^{-}=25 \\
\mathrm{MPa}\end{array}$ & $\begin{array}{c}\mathbf{f}_{\mathrm{c}}^{-}=\mathbf{3 0} \\
\mathrm{MPa}\end{array}$ & $\begin{array}{l}\mathrm{f}_{\mathrm{c}}^{-}=35 \\
\mathrm{MPa}\end{array}$ & $\begin{array}{l}\mathrm{f}_{\mathrm{c}}^{-}=40 \\
\mathrm{MPa}\end{array}$ & $\begin{array}{l}\text { \% Cost } \\
\text { savings }\end{array}$ \\
\hline \multirow{4}{*}{$\begin{array}{l}f_{y}=276 \\
\mathrm{MPa}\end{array}$} & Width-b (mm) & 342.9 & 333.1 & 326.2 & 321 & 317 & \multirow{4}{*}{5.367} \\
\hline & Effective depth-d (mm) & 691.8 & 670.2 & 655 & 643.7 & 634.9 & \\
\hline & Reinforcement ratio $(\rho)$ & 0.0171 & 0.0183 & 0.0193 & 0.02 & 0.0206 & \\
\hline & Optimum cost $\times C_{c}$ & 0.5627 & 0.5508 & 0.5428 & 0.5369 & 0.5325 & \\
\hline \multirow{4}{*}{$\begin{array}{l}\mathbf{f}_{\mathrm{y}}=345 \\
\mathrm{MPa}\end{array}$} & Width-b (mm) & 330.3 & 319.6 & 312.1 & 306.5 & 302.1 & \multirow{4}{*}{6.38} \\
\hline & Effective depth-d (mm) & 664.1 & 640.7 & 624.2 & 611.7 & 602 & \\
\hline & Reinforcement ratio $(\rho)$ & 0.0158 & 0.0171 & 0.0181 & 0.0189 & 0.0196 & \\
\hline & Optimum cost $\times C_{c}$ & 0.4999 & 0.4874 & 0.4789 & 0.4727 & 0.468 & \\
\hline \multirow{4}{*}{$\begin{array}{l}f_{y}=400 \\
\mathrm{MPa}\end{array}$} & Width-b (mm) & 322.9 & 311.7 & 303.8 & 297.7 & 293.1 & \multirow{4}{*}{7.12} \\
\hline & Effective depth-d (mm) & 647.8 & 623.3 & 605.8 & 592.5 & 582.3 & \\
\hline & Reinforcement ratio $(\rho)$ & 0.0149 & 0.0163 & 0.0173 & 0.0182 & 0.0189 & \\
\hline & Optimum cost $x C_{c}$ & 0.4634 & 0.4505 & 0.4417 & 0.4353 & 0.4304 & \\
\hline
\end{tabular}




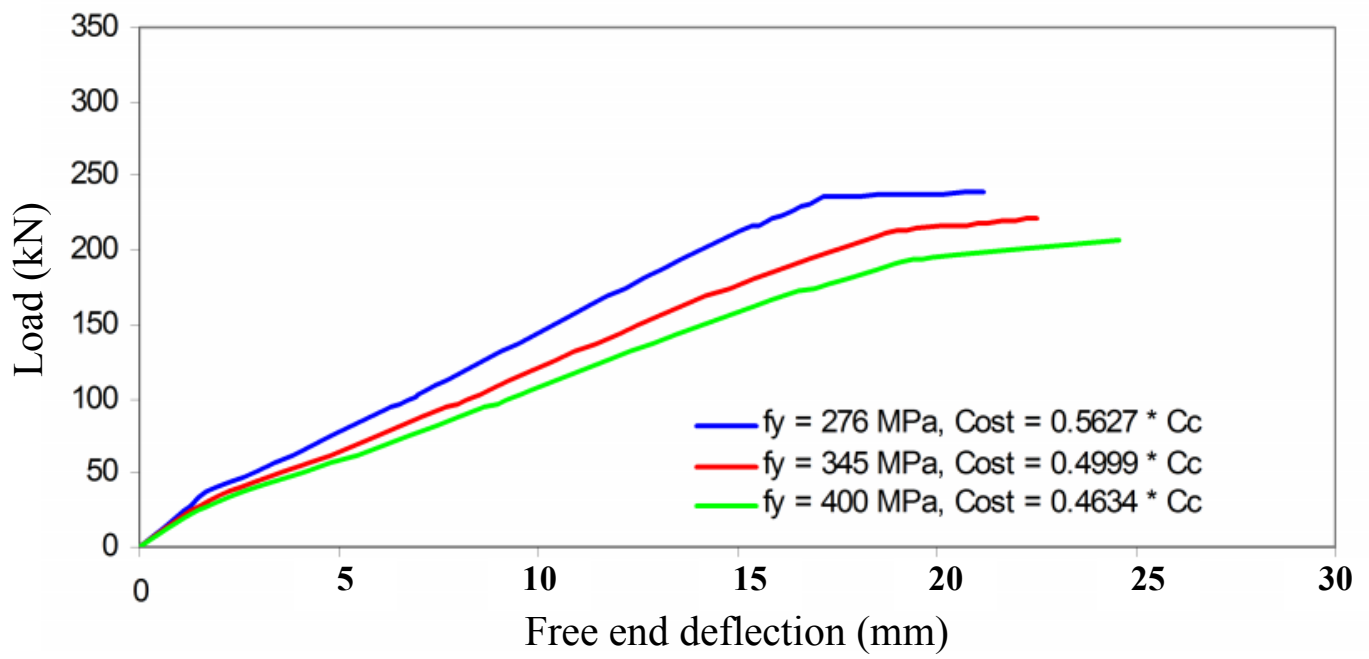

Fig. (10) Free end displacement of $3500 \mathrm{~mm}$ cantilever beam, $\mathrm{f}_{\mathrm{c}}{ }^{-}=20 \mathrm{MPa}$

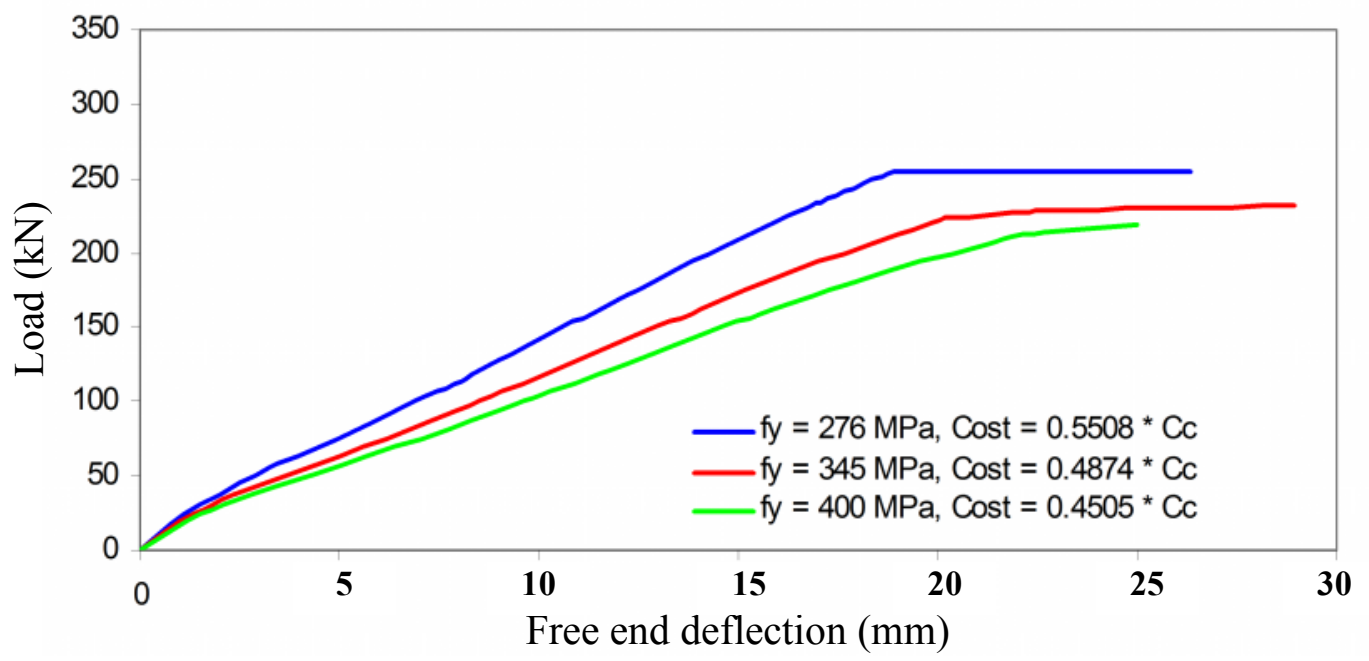

Fig. (11) Free end disnlacement of $3500 \mathrm{~mm}$ cantilever beam. $\mathrm{f}^{-}=25 \mathrm{MPa}$

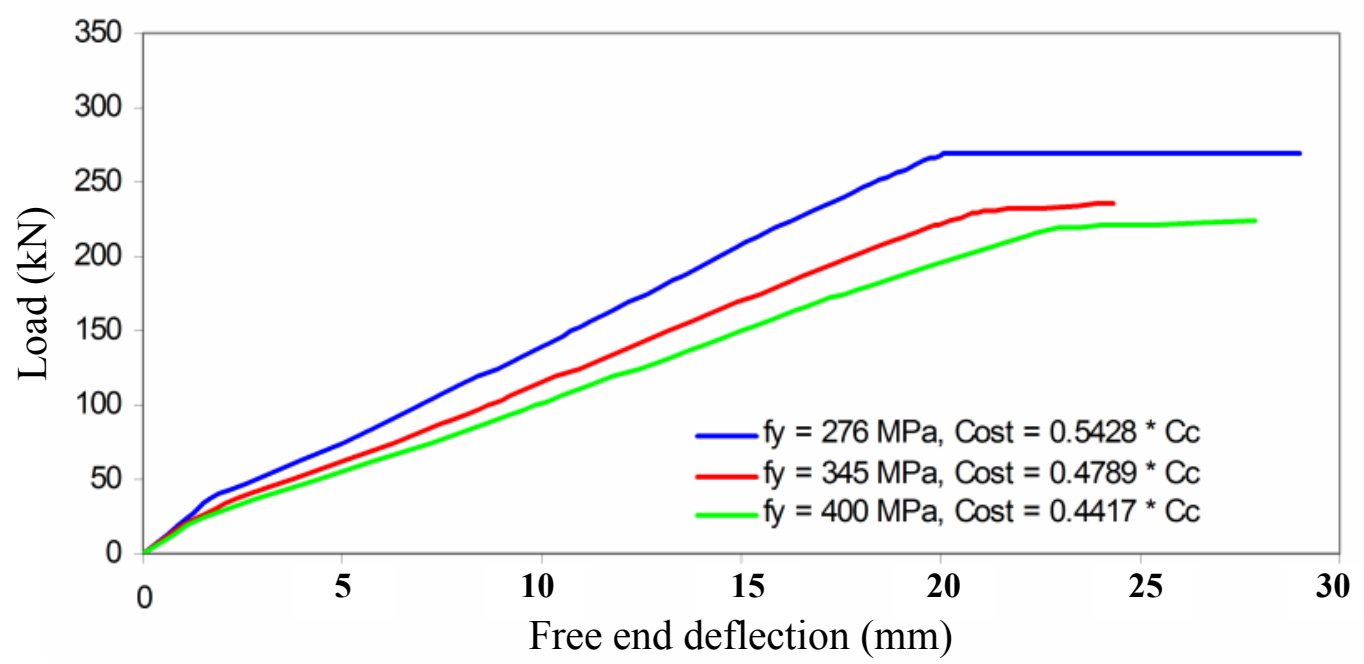

Fig. (12) Free end displacement of $3500 \mathrm{~mm}$ cantilever beam, $\mathrm{f}_{\mathrm{c}}^{-}=30 \mathrm{MPa}$ 


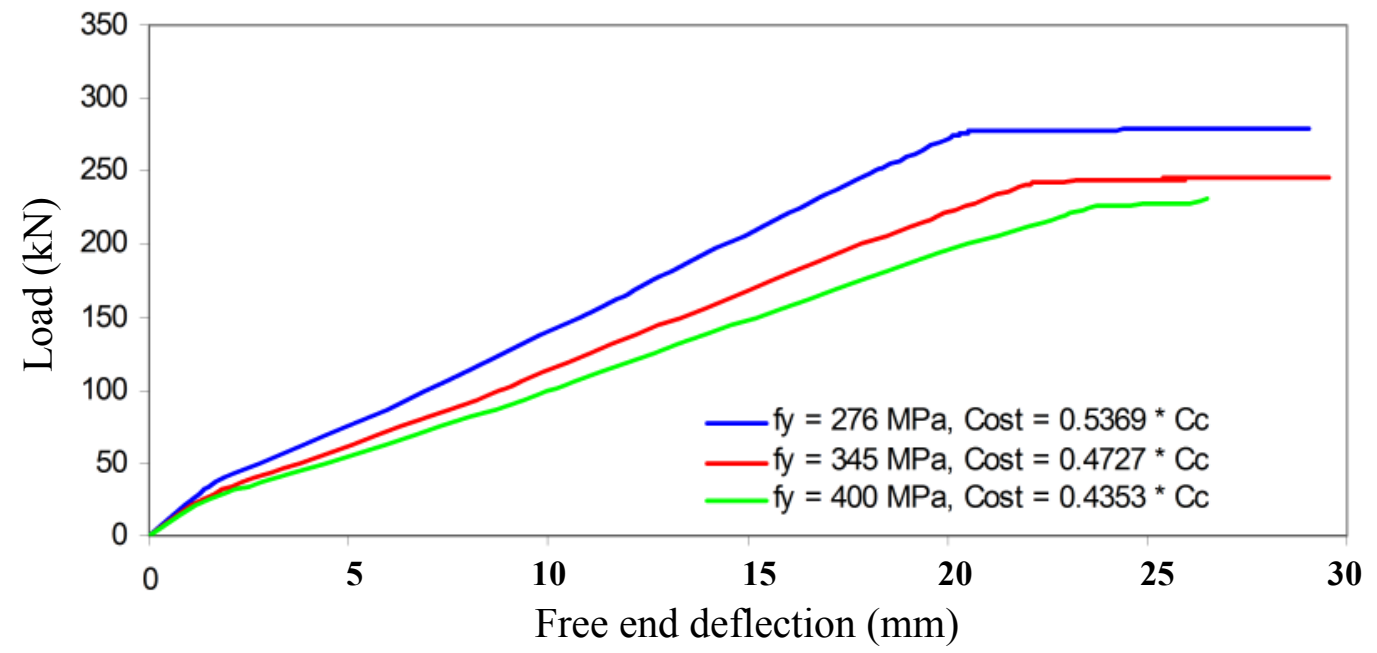

Fig. (13) Free end displacement of $3500 \mathrm{~mm}$ cantilever beam, $\mathrm{f}_{\mathrm{c}}^{-}=35 \mathrm{MPa}$

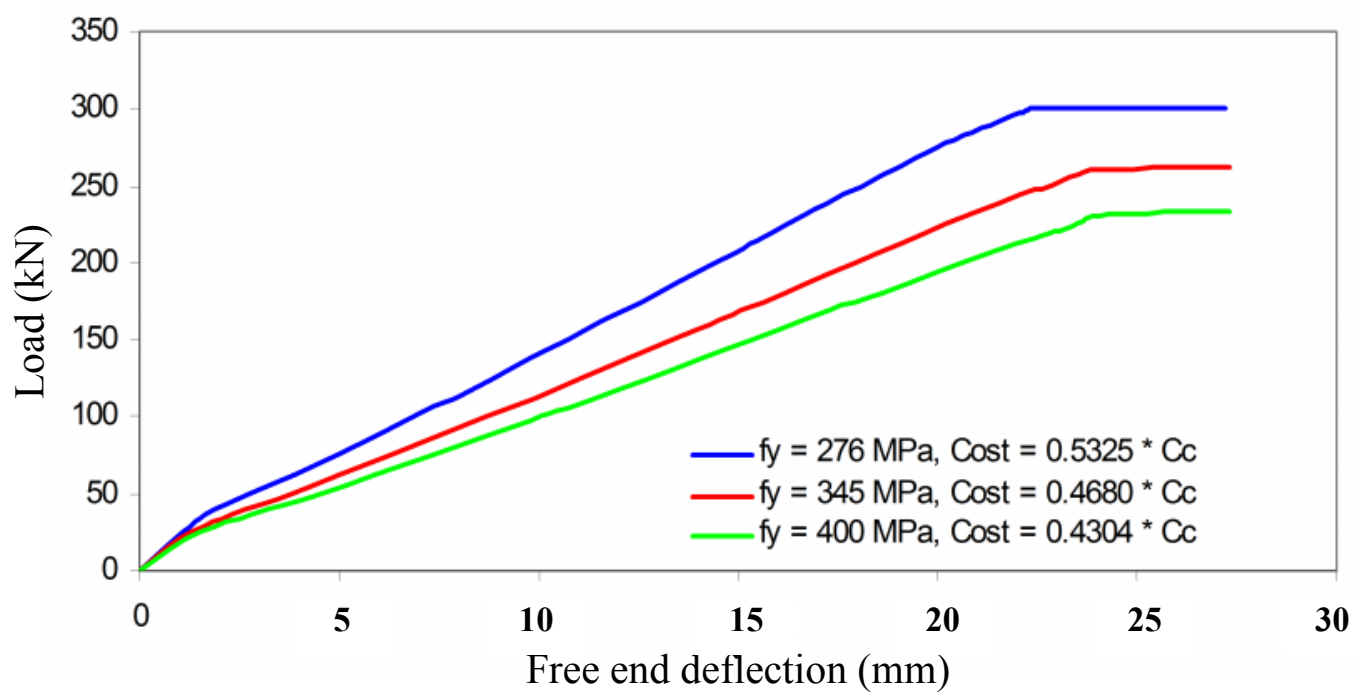

Fig. (14) Free end displacement of $3500 \mathrm{~mm}$ cantilever beam, $\mathrm{f}_{\mathrm{c}}{ }^{-}=40 \mathrm{MPa}$

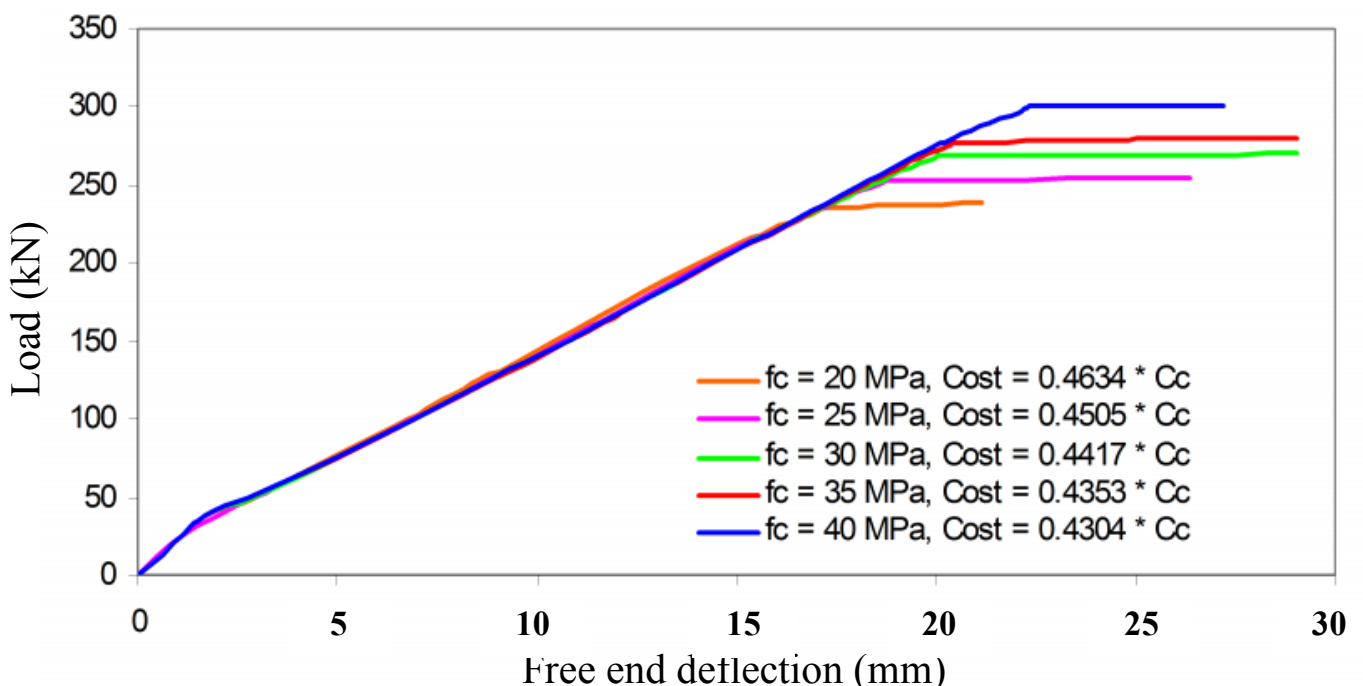

Fig. (15) Free end displacement of $3500 \mathrm{~mm}$ cantilever beam, $\mathrm{f}_{\mathrm{y}}=276 \mathrm{MPa}$ 


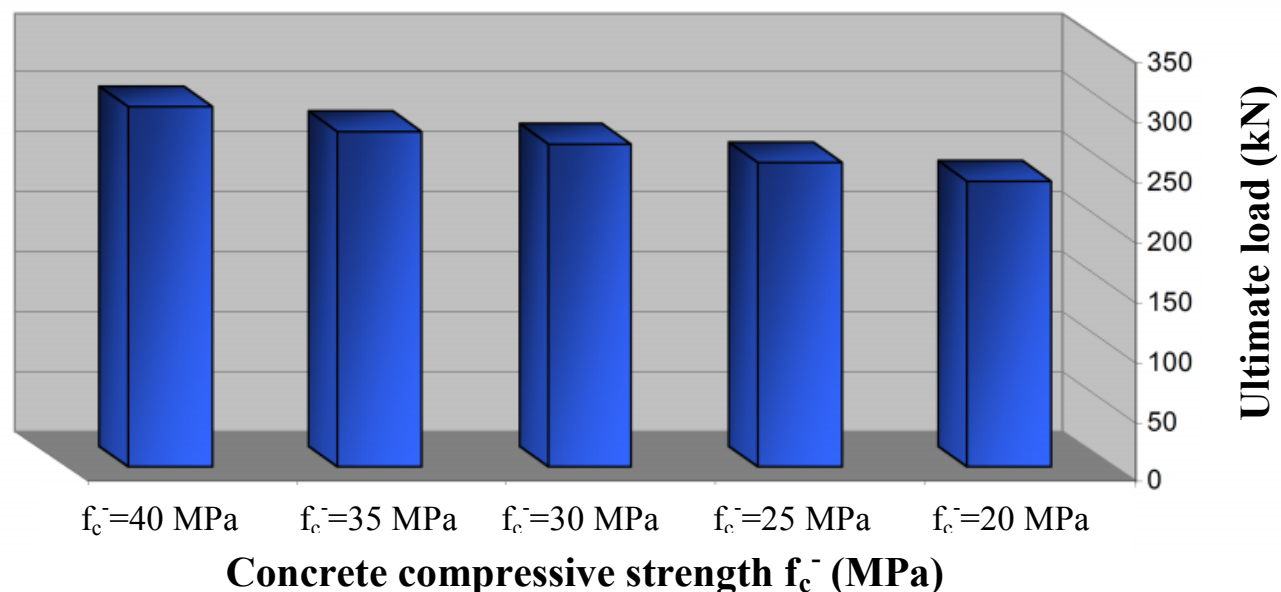

Fig. (16) Effect of fc on the ultimate load of the section, $f_{y}=276 \mathrm{MPa}$

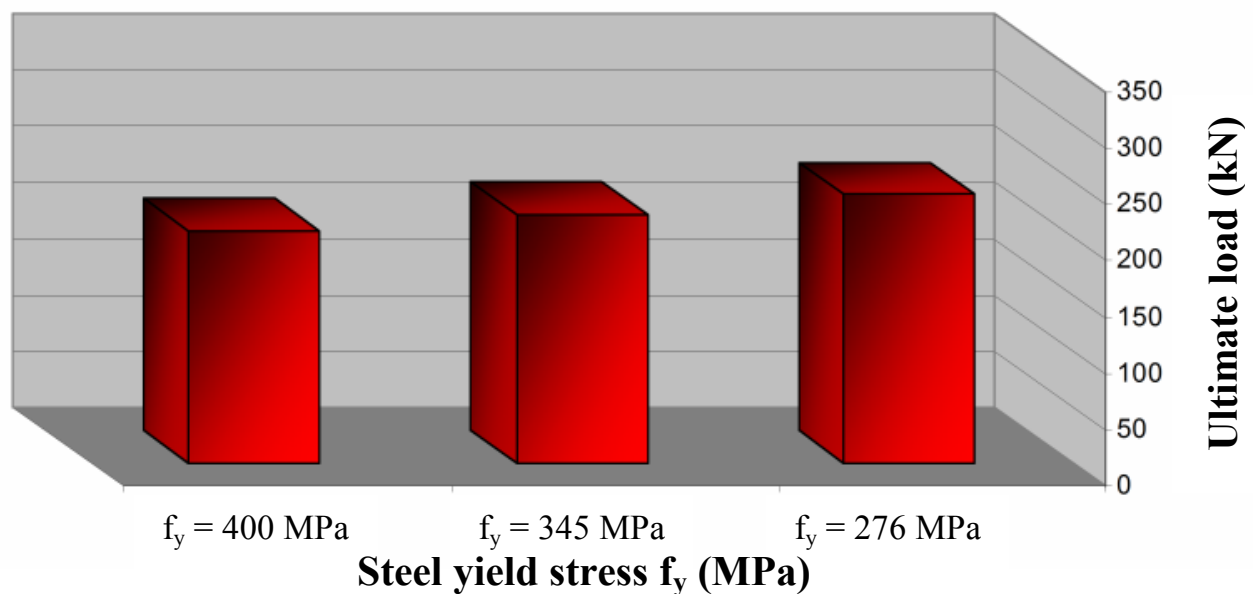

Fig. (17) Effect of fy on the ultimate load of the section, $f_{c}^{-}=20$ Mpa

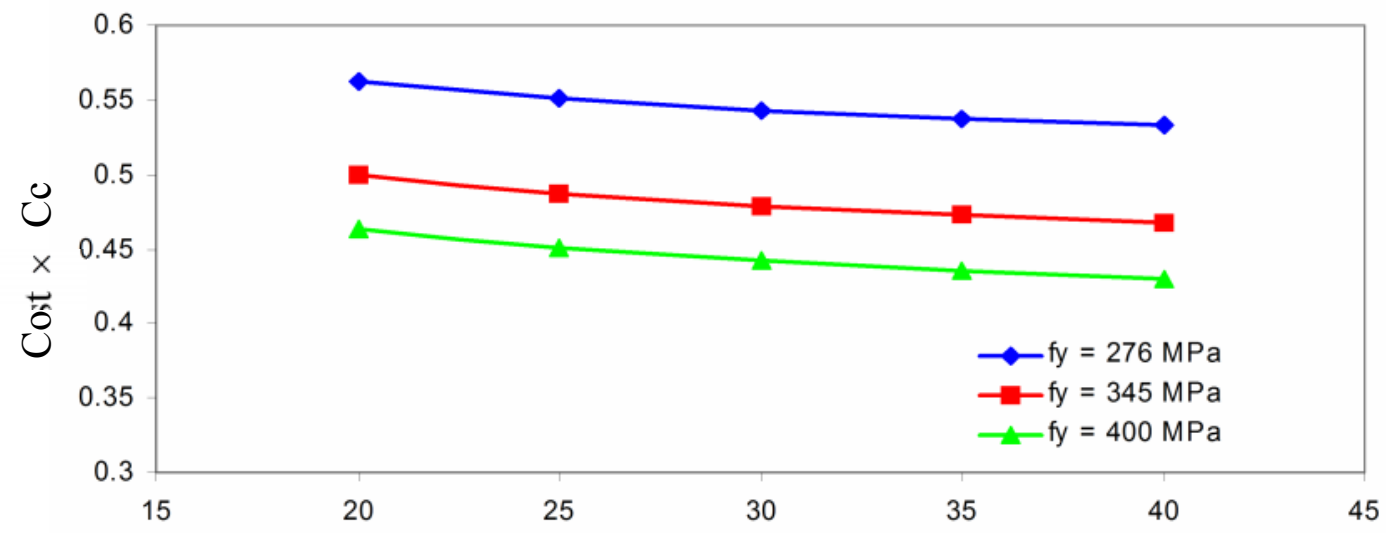

Concrete compressive strength $\mathrm{f}_{\mathrm{c}}^{-}$(MPa)

Fig. (18) Cost savings for optimum designed sections with different values of $f_{c}{ }^{-}$and $f_{y}$ 


\section{Conclusions}

The Genetic Algorithm proved that it is an adequate method for finding the optimum solution smoothly and flawlessly, especially for cases handling many complicated constraints such as beams subjected to moments, considering the limits of the design code.

There is no need for any reanalysis (whether it was a linear or non linear) to check the capacity of the designed section, as long as the design constraints of the used algorithm were sufficient and capable of achieving acceptable and reliable results, and there is no violations in them through the design procedure, and if there is any, it is recommended to use a penalty function in order to retreat the solution to the closest optimum.

For the optimum designed beams sections, increasing the concrete compressive strength increased the ultimate load of the section and reduced their costs by about $5-7 \%$. On the contrast, increasing the yield stress of the optimum section decreased the ultimate loads but also decreased its cost by about $17-19 \%$.

For optimum designed beam sections, increasing the compressive strength of concrete will be more effective than using a higher grade of steel yield stress in getting better results for the ultimate load. Meanwhile, seeking the optimum cost, the designer should control the reinforcing steel.

\section{References}

1 - Negnevitsky M., 2002, "Artificial Intelligence, a Guide to Intelligent Systems”, Addison Wesley.

2 - Lee C. and Ahn J., 2003, “Flexural Design of Reinforced Concrete Frames by Genetic Algorithm", Journal of Structural Engineering, Vol. 129, No. 6, pp. $762-774$.

3 - Guerra A. and Kiousis P. D., 2006, " Design Optimization of Reinforced Concrete Structures", Computers and Concrete, Vol. 3, No. 5, pp. $313-334$.

4 - Joghataie A. and Takalloozadeh M., 2009, "Improving Penalty Functions For Structural Optimization", Sharif University of Technology, Civil Engineering, Vol. 16, No. 4, pp. $308-320$.

5 - Yingjun W. and Mingqing S., 2010, “ The External Penalty Method For Optimization Design of Reinforced Concrete Underground Penstock", International Conference on Computing, Control And Industrial Engineering, pp. 345 - 347.

6 - Adedeji A. A., 2011, " Searching For The Optimal Design Variables of RC Flat Slab By The Reactive Taboo", Trends in Applied Science Research, Vol. 6, No. 4, pp. 375 - 385.

7 - Albuquerque A. T., Debs M. K. and Melo A. M. C., 2012, “A Cost Optimization - Based Design of Precast Concrete Floors Using Genetic Algorithm", Automation in Construction, No. 22, pp. 348 - 356.

8 - Govindaraj V. and Ramasamy J. V., 2005, “ Optimum Detailed Design of Reinforced Concrete Continuous Beams Using Genetic Algorithm”, Computers and Structures, No. 84 , pp. $34-48$.

9 - Adeli H. and Sarma K. C., 2006, “Cost Optimization of Structures”, John Wiley \& Sons Ltd.

10 - Hinton E. and Owen D. R. J., 1984, "Finite Elements Software For Plates And Shells", Pineridge Press Limited.

The work was carried out at the college of Engineering. University of Mosul 